\title{
Strategi Muslim Mempertahankan Kerukunan Umat Beragama Sebagai Wujud Nilai Pendidikan Bertoleransi Di Graha Maria Annai Velangkanni Sumatera Utara Medan
}

\author{
Asfiati $^{1}$ \\ asfiati@iain-padangsidimpuan.ac.id
}

\begin{abstract}
Religious harmony is talking about the inner atmosphere. Every religion teaches goodness and invites the truth. Muslim strategy to maintain religious harmony as a form of the value of tolerant education around Graha Maria Annai Velangkanni needs to be explored. The research method uses a sociological approach with the type of qualitative research. The subject of the research is the Muslim community who live around Graha Maria Annai Velangkanni Medan, North Sumatra. Data collection techniques through observation, in-depth interviews and discussion group forums. The results of this study indicate that the Muslim strategy to maintain religious harmony as a form of the value of tolerant education around Graha Maria Annai Velangkanni North Sumatra Medan is carried out with the following steps: Building religious harmony with the intentions and awareness of fellow humans. Build social cultures and make cooperation. Hold dialogues and meetings between religious leaders, community leaders and through social and family approaches. Creating an understanding of noble values, cultural values for dialogue in friendly and mutual respect. The motivating factors for the Muslim community to maintain religious harmony as a form of the value of tolerant education around Graha Maria Annai Velangkanni North Sumatra Medan, are: the factor of awareness and mutual raising of fellow creatures created by God. The intention factor to study different cultural and religious customs. Openness factor.
\end{abstract}

keywords: Religious Harmony, Tolerant Educational Values, Muslim Strategies

\section{ABSTRAK}

Kerukunan umat beragama adalah berbicara suasana bathin. Setiap agama mengajarkan kebaikan dan mengajak kepada kebenaran. Strategi muslim mepertahankan kerkunan umat beragama sebagai wujud nilai pendidikan bertoleransi di sekitar Graha Maria Annai Velangkanni perlu ditelusuri. Metode penelitian menggunakan pendekatan sosiologis dengan jenis penelitian kualitatif. Subjek penelitan adalah masyarakat muslim yang berdomisili di sekitar Graha Maria Annai Velangkanni Medan Sumatera Utara. Teknik pengumpulan data melalui observasi, wawancara mendalam dan forum group diskusi. Adapun hasil penelitian ini menunjukkan bahwa strategi muslim mempertahankan kerukunan beragama sebagai wujud nilai pendidikan bertoleransi di sekitar Graha Maria Annai Velangkanni Sumatera Utara Medan

\footnotetext{
${ }^{1}$ Dosen Institut Agama Islam Negeri Padangsidimpuan
} 
dilakukan dengan langkah-langkah, berikut: Membangun harmonisasi beragama dengan niat dan kesadaran sesama manusia. Membangun budayabudaya sosial dan menjadikan ada kerja sama. Mengadakan dialog dan pertemuan antar pemuka agama, tokoh masyarakat dan melalui pendekatan sosial dan kekeluargaan. Menciptatkan pemahaman nilai-nilai luhur, nilai-nilai budaya untuk berdialog dalam ramah dan saling menghormati. Adapun faktor pendorong masyarakat muslim mempertahankan kerukunan beragama sebagai wujud nilai pendidikan bertoleransi di sekitar Graha Maria Annai Velangkanni Sumatera Utara Medan, adalah: faktor kesadaran dan saling membesarkan sesama makhluk ciptaan Tuhan. Faktor niat untuk mempelajari budaya dan adat agama yang berbeda. Faktor keterbukaan.

Kata Kunci: Kerukunan Umat Beragama, Nilai Pendidikan Bertoleransi, Strategi Muslim

\section{A. PEndahuluan}

Kerukunan umat beragama adalah kondisi yang sangat dinamis dan majemuk. Kerukunan umat beragama pertama kali dikemukakan oleh Menteri Agama, K.H. M. Dachlan. Dalam pidato pembukaan Musyawarah Antar Agama tanggal 30 Nopember 1967 beliau menyatakan: "adanya kerukunan antara golongan beragama adalah merupakan syarat mutlak bagi terwujudnya nilai pendidikan bertoleransi, tstabilitas politik dan ekonomi yang menjadi program Kabinet Ampera. Kerukunan beragama merupakan cita-cita bangsa Indonesia mewujudkan nilai pendidikan bertoleransi dalam masyarakat adil dan makmur yang dilindungi Tuhan Yang Maha Esa. ${ }^{2}$

Kondisi kerukunan umat beragama dapat dikatakan, secara umum berjalan baik dan harmonis. Indonesia mendapat perhatian dunia internasional terkait penyelesaian konflik-konflik bernuansa agama. Sejumlah negara telah berkunjung untuk belajar dari pengalaman Indonesia dalam menyelesaikan konflik tersebut. ${ }^{3}$

Kunjungan beberapa negara ini membawa berita baik bagi penganut agama Khatolik di kota Medan Sumatera Utara. Medan adalah kota multietnis yang mana penduduknya terdiri dari orang-orang dengan latar belakang budaya, pendidikan dan agama yang berbeda-beda. Selain Melayu dan Karo sebagai penghuni awal, Medan didominasi oleh etnis Jawa, Batak, Tionghoa, Mandailing, dan India. ${ }^{4}$.

\footnotetext{
${ }^{2}$ Ibnu Rusydi and Siti Zolehah, "Makna Kerukunan Umat Beragama Dalam Konteks Keislaman Dan Keindonesian,” Journal for Islamic Studies 1, no. 1 (2018): 170-81, https://doi.org/10.5281/zenodo.1161580.

${ }^{3}$ Haidlor Ali Ahmad, Survey Kerukunan Umat Beragama Di Indonesia (Jakarta: Puslitbang Kehidupan Keagamaan Badan Litbang dan Diklat Kementerian Agama RI, 2013).

${ }^{4}$ Wikipedia, "Wikipedia Bahasa Indonesia, Ensiklopedia Bebas," 2018, https://id.wikipedia.org/wiki/Fotosintesis.
} 
India sebagai salah satu etnis yang ada di kota Medan memiliki rumah atau tempat suci yang dalam bahasa Sankrit disebut Kuil. Graha Maria Annai Velangkanni telah dibangun di kota Medan pada tahun 2005, terletak di pinggiran kota Medan, Sumatera Utara, Indonesia. ${ }^{5}$

Kehadiran sebuah rumah ibadah sering mengganggu hubungan antar umat beragama. Kehadiran rumah ibadah kemungkinan bisa memicu konflik karena lokasinya di tengah komunitas kebanyakan menganut agama lain. ${ }^{6}$ Akan tetapi berbeda dengan masyarakat muslim dan agama lain di sekitar dibangunnya rumah ibadah Khatolik Graha Maria Annai Velangkanni. Masyarakat komplek Perumahan Sakura Indah yang mayoritas muslim tetap mempertahankan sikap saling menghargai dan penuh egalitarianism. Masyarakat terbuka dan saling menyapa satu sama lain. Masyarakat senantiasa menunjukkan sikap penuh persaudaraan dan toleransi karena Islam sendiri mengajarkan untuk saling berlomba-lomba dalam berbuat kebajikan.

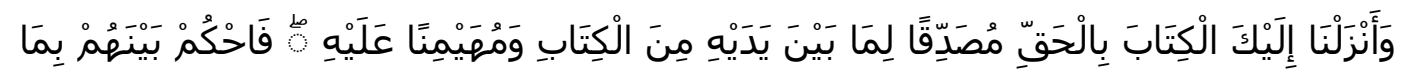

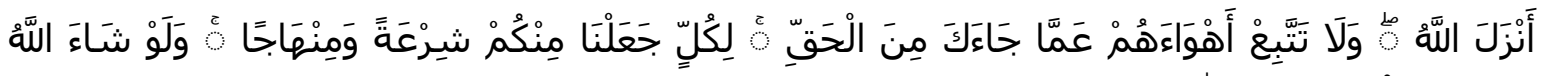

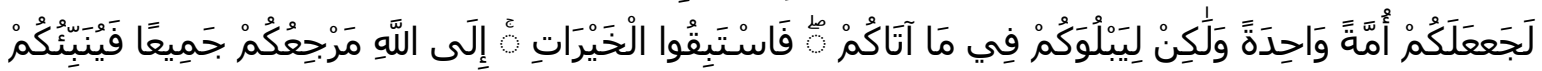
بِمَا كُنتُمْ فِيهِ تَخْتَلِفُونَ

Artinya: "Untuk tiap-tiap umat di antara kamu, Kami berikan aturan dan jalan. Seandainya Allah menghendaki, niscaya Dia menjadikan kamu satu umat, tetapi Allah hendak menguji kamu mengenai pemberian-Nya kepadamu, maka berlomba-lombalah berbuat kebajikan.” (QS Al-Maidah [5]: 48)

Seorang Muslim dapat memahami adanya pandangan yang berbeda. Perbedaan bukanlah jurang untuk berbuat jahat. Berlombalah dalam setiap kebajikan niscaya Allah akan selalu beri petunjuk dan bimbingan. Muslim yang taat senantiasa berupaya membentuk persatuan yang indah. Nilai-nilai estetika dan kepercayaan menyatu untuk mengekspresikan keagungan dan kebesaran Ilahi. Nilai-nilai pendidikan dengan bertoleransi antara umat beragama yang berbeda latar belakang pendidikan. Masing-

\footnotetext{
${ }^{5}$ James Bharatputra, "Mengenai Graha Maria Annai Velangkanni,” 2019.

${ }^{6}$ Saidurrahman \& Arifinsyah, Nalar Kerukunan_ Merawat Keragaman Bangsa Mengawal NKRI (Jakarta:
} Kencana, 2018). 
masing masyarakat yang mempunyai pendidikan dan agama yang berbeda senantiasa menjalankan agama dan kepercayaannya.

Agama Islam dengan konsep hablum minannas mengadakan interaksi sosial dengan para pengunjung kuil Graha Maria Annai Velangkanni. Agama Hindu dengan ajaran tripitaka membangun kerja sama dengan para wisata rohani yang berkunjung ke Graha Maria Annai Velangkanni. Graha Maria Annai Velangkanni menjadi sebuah tempat di mana semua orang dari berbagai ras dan agama, kaya atau miskin menjadi tujuan wisata. Sehingga masyarakat sekitarpun berupaya saling menyapa, tersenyum dan saling memberikan jasa dengan tidak merusak aqidah. Nilai pendidikan bertoleransi sangat tercermin dalam setiap aktivitas di lingkungan umat yang berbeda suku, ras dan agama.

Suasana yang berada dalam keadaan selaras, tentram, tanpa perselisihan serta bersatu. Suasana dalam rangka saling membantu merupakan suatu wujud nilai-nilai pendidikan bertoleransi. Kerukunan yang merupakan suatu keberadaan semua pihak berada dalam keadaan damai satu sama lain. Keadaan yang sama-sama suka bekerja sama, saling menerima dalam suasana tenang dan harmonis, sehati dan tidak berseteru. ${ }^{7}$.

Walaupun saat ini zaman semakin memperluas jurang antara sesama manusia. Di mana zaman ini adalah era disrupsi. Era di mana media sosial merupakan media online sebagai bagian dari hidup. Media sosial keliaran dalam sikap dalam perilaku beragama. ${ }^{8}$, Namun era disrupsi ini harus dibuktikan dengan realita sosial keberagamaan. Nilai pendidikan toleransi mesti diwujudkan dalam bentuk kerukunan beragama. Kerukunan beragama jangan pudar hanya karena salah penafsiran terhadap hal yang kelihatan di media sosial. Akan tetapi buktikan dengan dunia nyata. Maknanya silih bergantinya pengunjung Graha Maria Annai Velangkanni dari berbagai suku agama dan ras harus dimaknai bahwa apa yang dilihat itulah yang dirasakan.

Dengan demikian kerukunan sebagai suatu kondisi sosial yang ditandai dengan adanya keharmonisan, keselarasan dan tidak berseteru merupakan proses yang harus dipertahankan dan dipelihara baik dalam pola interaksi yang beragam etnis, strata, dan

${ }^{7}$ Erwin Kusumastuti, "Strategi Dan Praktek Kerukunan Beragama Dalam Persfektif Pendidikan Multikultural: Studi Di Desa Ponggok, Polanharjo, Klaten,” 2016.

${ }^{8}$ Reza Bakhtiar Ramadhan Aris Ridiana, "Dakwah Virtual Sebagai Banalitas Keberagaman Di Era Disrupsi," Jurnal Ilmu Aqidah Dan Studi Keagamaan 7, no. 1 (2019): h.137. 
kelompok agama yang berbeda. Kerukunan umat beragama merupakan ejawantah dari nilai pendidikan oleransi sebagai salah satu nilai pendiidkan ajaran agama Islam. Masyarakat muslim di sekitar Graha Maria Annai Velangkanni tidak merasa terusik dengan dibangunnya rumah ibadah agama Katholik tersebut. Masyarakat muslim mempunyai tepa seliro yang dapat dipertahankan dan dimaknai. Atas dasar suasana yang penuh bermakna inilah peneliti ingin menelusuri Strategi Muslim Mempertahankan Kerukunan Umat Beragama Sebagai Wujud NIlai Pendiikan Bertoleransi di Graha Maria Annai Velangkanni Sumatera Utara Medan agar dapat dijadikan contoh dalam memupuk keberbedaan untuk kebersamaan. Dijadikan sebagai pengamalan nilai-nilai pendidikan agama Islam.

\section{PENGERTIAN STRATEGI MUSLIM}

Keberhasilan kegiatan secara efektif banyak ditentukan oleh penentuan strategi. ${ }^{9}$ Di lain pihak jika tidak ada strategi yang baik efek dari proses akan menimbulkan pengaruh negatif. Sementara itu untuk menilai proses dari sebuah strategi dapat ditelaah dengan menggunakan berbagai cara, gaya, model, taktik serta pendekatan. ${ }^{10}$ Dalam proses mempertahankan kerukunan umat beragama kegiatan yang sedang berlangsung atau sudah selesai prosesnya. Menilai keberhasilan strategi dari proses yang digunakan itu sendiri. Strategi merupakan panduan dari perencanaan untuk mencapai suatu tujuan. ${ }^{11}$ Dalam realitas strategi harus dapat menunjukkan bagaimana operasionalnya secara taktis harus dilakukan, dalam makna bahwa pendekatan (approach) bisa berbeda sewaktuwaktu.

Strategi muslim dalam hal ini adalah adanya hak dan kebebasan seorang atau sekelompok muslim menentukan prinsif dalam sebuah proses sesuai dengan pandangan hidup Islam. Salah satu prinsip yang dilakukan adalah kebebasan beragama. ${ }^{12}$. Adanya dalam diri muslim strategi bahwa bebas beragama merupakan kehormatan bagi manusia dari Tuhan. Muslim yang sudah menentukan pilihan terhadap kebebasan beragama niscaya tertanam perilaku tanggung jawab sepenuhnya dalam diri muslim itu sendiri.

Q.S al Baqoroh ayat 256 yang artinya "Tidak ada paksaan dalam memeluk agama. Sungguh telah jelas antara kebenaran dan kesesatan" (QS. Al Baqarah: 256) bermakna bahwa Islam memberi kebebasan kepada manusia untuk memeluk agama apa saja, dan agama apapun dapat mengantarkan pemeluknya kepada Surga Allah Ta'ala.

\footnotetext{
${ }^{9}$ Muhammad Salim, "Implementasi Pendekatan Saintifik Dalam Pembelajaran Pendidikan Agama Islam Dan Budi Pekerti Di Sd Negeri Baran, Patuk, Gunungkidul” (UIN Sunan Kalijaga, 2017).

${ }^{10}$ Iswan dan Herwina, "Penguatan Pendidikan Karakter Persfektif Islam Dalam Era Millenial IR 4.0," Umj 1, no. 1 (2018): 21-42, https://jurnal.umj.ac.id/index.php/SNP/article/view/2756/2261.

${ }^{11}$ Asfiati, Pendekatan Humanis Dalam Pengembangan Kurikulum (Bandung: Perdana Publishing, 2016).

${ }^{12}$ Kartika Nur Utami, “Kebebasan Beragama Dalam Perspektif Al-Qur'an,” Kalimah (Jakarta: Infas, 2018), https://doi.org/10.21111/klm.v16i1.2511.
} 
Seorang manusia dianggap sudah mampu dan harus diberi kebebasan untuk membedakan dan memilih sendiri mana yang benar dan mana yang salah. Dalam pandangan hidup Islam, anugerah yang diturunkan Allah kepada manusia adalah kebebasan untuk memilih sendiri agamanya yang mana berdasarkan dari keyakinannya sendiri. Hal inilah yang membuat manusia berbeda dengan makhluk Allah yang lain. Jalan hidup utama yang diberikan kepada manusia adalah kebebasan untuk mengikuti petunjuk yang diturunkan melalui Nabi Muhammad SAW, yaitu agama Islam, yaitu jalan yang paling benar, ataupun memeluk keyakinan agama lain, semuanya diserahkan secara penuh kepada manusia.

Makna dari beragama yaitu memeluk agama atau kepercayaan tertentu adalah suatu sikap yang tidak terikat atau merdeka untuk memeluk sesuatu agama atau keyakinan yang diinginkan. Setiap muslim memiliki hak untuk beragama dan hak-hak kebebasan lain.

Strategi bermu'amalah antar umat beragama (non-muslim) dapat dijadikan dalam mempertahankan kerukunan umat beragama sebagai wujud nilai pendidikan Islam. Dalam hal ini sikap untuk dapat hidup bersama masyarakat penganut agama lain, dengan memiliki kebebasan untuk menjalankan prinsip-prinsip keagamaan (ibadah) masingmasing, tanpa adanya paksaan dan tekanan, ${ }^{13}$.

\section{MEMPERTAHANKAN KERUKUNAN UMAT BERAGAMA}

Kerukunan berasal dari bahasa Arab dari kata ruknun jamaknya arkan berarti: "asas atau dasar". ${ }^{14}$. Kerukunan hidup umat beragama, bermakna ada kebersamaan baik di luar pergaulan atau sesama. Kerukunan umat beragama terciptanya suatu hubungan yang harmonis dan dinamis serta rukun dan damai di antara sesama umat beragama di di mana saja pun berada.

Konsep Islam, mendefinisikan bahwa kerukunan diberi istilah tasamuh (toleransi) yang berarti kerukunan sosial kemasyarakatan. Di mana antara sesama muslim mempunyai kehidupan saling membutuhkan. Hakikat hidup bersama dalam masyarakat dengan "kesatuan hati" dan bersepakat" untuk tidak menciptakan perselisihan dan pertengkaran. Kerukunan" adalah sesuatu yang ideal dan didambakan oleh masyarakat manusia. ${ }^{15}$ Kerukunan secara luas bermakna adanya suasana persaudaraan dan dan kebersamaan antar semua orang walaupun mereka berbeda secara suku, agama, dan golongan. Kerukunan juga bisa bermakna suatu proses untuk menjadi rukun. Adapun langkah-langkah untuk mencapai kebersamaan memerlukan proses atau strategi. Proses

\footnotetext{
2 (2018): h.

${ }^{13}$ Dewi Murni, “Toleransi Dan Kebebasan Beragama Dalam Persfektif Al-Quran,” Jurnal Syahadah VI, no.

${ }^{14}$ Mawardi, "Reaktualisasi Kerukunan Antar Umat Beragama Dalam Kemajemukan Sosial,” Substantia 17, no. April (2015): 55-66.

${ }^{15}$ Nazmudin Nazmudin, "Kerukunan Dan Toleransi Antar Umat Beragama Dalam Membangun Keutuhan Negara Kesatuan Republik Indonesia (NKRI)," Journal of Government and Civil Society 1, no. 1 (2018): 23, https://doi.org/10.31000/jgcs.v1i1.268.
} 
tersebut dari adanya waktu yang diluangkan untuk dialog bersama, saling terbuka, dan menerima dan menghargai satu sama lain. Langkah-langkah berikut dapat juga dilakukan dalam mempertahankan kerukunan umat beragama sesuai dengan nilai pendidikan agama Islam wujud nilai pendidikan bertoleransi, yaitu:

a. Membangun harmonisasi beragama dengan dibentengi oleh niat dan kesadaran sesama manusia.

b. Membangun budaya-budaya sosial dalam satu lingkaran geografis menjadikan ada kerja sama. Hal ini diwujudkan dengan dialog dan pertemuan antar pemuka agama, tokoh masyarakat dan melalui pendekatan sosial dan kekeluargaan.

c. Menciptatkan pemahaman nilai-nilai luhur, nilai-nilai budaya untuk berdialog dalam ranah saling menghormati. 16

Kerukunan umat beragama sebagai satu kesatuan jiwa dalam urusan bersosial dan bermasyarakat dapat dilakukan dengan cara berikut:

a. Berperan serta dalam masyarakat dengan asas saling mempunyai tanggung jawab terhadap masing-masing agama yang dianut.

b. Membangun komunikasi yang satu penafsiran agar umatsaling memahami dan saling memaknai.

c. Menjalin komunikasi di semua tingkat kehidupan umat. Kehidupan dalam bidang sosial, masyarakat, budaya, pendidikan. ${ }^{17}$

Masing-masing teori itu dapat dijadikan indikator dalam mempertahankan kerukunan umat beragama. Hanya strategi yang disusun rapi sesuai dengan focus dan kondisi keberagamaan yang terjadi.

\section{GRAHA MARIA ANNAI VELANGKANNI SUMATERA UTARA MEDAN}

Graha Maria Annai Velangkanni adalah gereja Katolik bergaya India-Mughal yang dibuka pada tahun 2005 di kota Medan, Indonesia. Gereja ini dipersembahkan untuk Bunda Velangkanni Bunda Penyembuh (bahasa Tamil.Gereja ini merupakan bangunan dua tingkat yang terdiri dari tempat pertemuan di lantai dasar dan tempat ibadah di lantai pertama, sementara menara di atasnya terdiri dari tujuh lantai sebagai lambang bahwa di surga terdapat tempat untuk semua orang. Menara ini sendiri merupakan perwakilan Raja Gopuram (kubah raja) dalam arsitektur Hindu. Di atas bangunan gereja ini juga terdapat tiga kubah yang dibangun dengan gaya arsitektur Mughal dan merupakan lambang Tritunggal. Gereja ini terletak di sebuah jalan kecil yang bernama Jl. Sakura III Komplek Perumahan Sakura Tanjung Selamat Medan Tuntungan.

Bangunan Graha Maria Annai Velangkanni di pinggiran kota Medan ini tepatnya di komplek Perumahan Sakura Indah Tanjung Selamat Medan Tuntungan dibangun oleh

\footnotetext{
${ }^{16}$ Rahmini Hadi, "Pola Kerukunan Umat Beragama Di Banyumas,” Ibda Jurnal Kebudayaaan Islam IV, no. 1 (2016): h.

${ }^{17}$ Hakis, "Komunikasi Antar Umat Beragama Di Kota Ambon," Jurnal Komunikasi Islam 05, no. 1 (2015): 99-113.
} 
para donator Indonesia, 10\% dari India, Malaysia dan Singapura dan 30\% datang dari satu keluarga Cina di Singapura (Philip Tong Guan Beng \& Grace Tong-Lam Chi Lian) sebagai bentuk dorongan karena Indonesia adalah negara yang damai aman dan tinggi solidaritas keberagamaan. Graha Maria Annai Velangkanni membawa perubahan bagi masyarakat sekitar. Tanjung Selamat adalah kelurahan di kecamatan Medan Tuntungan, Medan, Sumatra Utara, Indonesia. ${ }^{18}$.
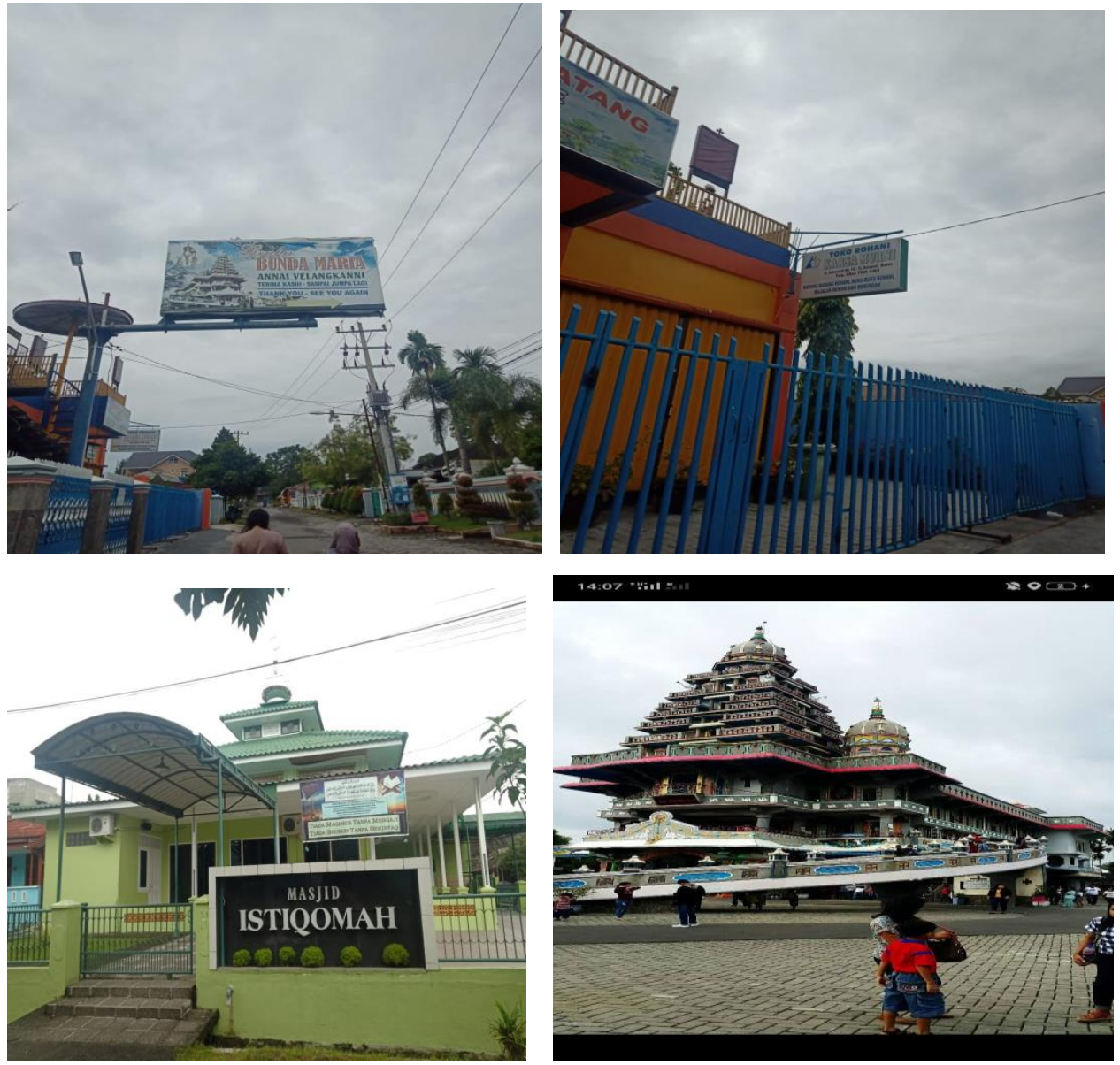

\section{B. KERANGKA KONSEPTUAL}

Makna kerukunan cenderung ke pada kabaikan. Baik dalam hal berbuat dan bertindak. Aktivitas dalam sebuah kegiatan keberagmaan. Social dan budaya dicerminkan dengan saling memahami dan mengerti rasa. Terbangunnya rasa saling sepakat saling berusaha membangun kedamaian dan kesejahteraan di mana pun berada. Demikian halnya di lingkungan masyarakat yang heterogen. Perbedaan tentunya menjadikan adanya saling menghargai dan saling mengambil hati. Perbedaan berupaya untuk saling menyamakan persepsi dan visi. Perbedaan mampu mengembangkan kekrabatan dan

18 (Wikipedia bahasa Indonesia, 2019) 
persaudaraan. Persaudaraan dalam konsep Islam adalah terbangunnya hidup berdampingan dan bersama dengan damai serta tentram.

Damainya dinamika kehidupan umat beragama dalam segala aspek kehidupan. Islam mengajarkan manusia ditakdirkan Allah sebagai makhluk sosial yang membutuhkan hubungan dan interaksi sosial dengan sesama manusia. Manusia sebagai makhluk sosial memerlukan kerja sama dengan orang lain dalam memenuhi kebutuhan hidupnya, baik kebutuhan material maupun spiritual. Demikian halnya dengan pengunjung rumah ibadah Graha Maria Annai Velangkanni Medan Sumatera Utara. Pengunjung yang beragama Khatolik dan agama lainnya melakukan ibadah di kuil Graha Maria Annai Velangkanni. Kuil Graha Maria Annai Velangkanni yang didirikan sejak tahun 2005 merupakan rumah ibadah yang dijadikan sebagai tempat ziarah dan kunjungan rohani. Dibangunnya rumah Graha Maria Annai Velangkanni tidak memicu kebisingan dan kesemrawutan di daerah sekitar kuil. Hal ini membuktikan masyrakat muslim di sekitar Graha Maria Annai Velangkanni menjunjung tinggi kerukunan beragama. Sekalipun dalam teori ditemukan dibangunnya rumah ibadah baru di lingkungan yang beda agama dapat memicu terjadinya ketidakharmonisan.

Masyarakat muslim di sekitar rumah ibadah Graha Maria Annai Velangkanni ajaran tentunya mempunyai strategi yang patut dibudidayakan. Strategi tersebut juga dilihat apakah sejalan dengan teori Islam. Di mana Islam menganjurkan manusia untuk bekerja sama dan tolong menolong (ta'awun) dengan sesama manusia dalam hal kebaikan. Dalam kehidupan sosial kemasyarakatan umat Islam dapat berhubungan dengan siapa saja tanpa batasan suku, ras, bangsa, dan agama. Dalam konteks ini kerukunan umat beragama merupakan pilar kerukunan nasional adalah sesuatu yang dinamis, karena itu haus dipelihara terus dari waktu ke waktu.

Kerukunan hidup umat beragama sendiri berarti keadaan hubungan sesama umat beragama yang dilandasi toleransi, saling pengertian, menghargai kesetaraan dalam pengamalan ajaran.

\section{METODOLOGI PENELITIAN}

\section{Sumber data.}

Adapun sumber data penelitian ini terdiri dari sumber data primer dan sekunder. Sumber data primer diperoleh dari hasil observasi dan wawancara dengan informan. Sumber data primer 
adalah: masyarakat muslim, pemuka agama, tokoh masyarakat, pemerintah, pengurus graha dan pengunjung wisata rohani.

Sumber data sekunder diperoleh dari pustaka yang diambil dari jurnal ilmiah, maupun buku-buku induk yang relevan dengan kajian penelitian.

\section{Jenis Data}

Jenis data penelitian diklasifikasikan menjadi dua macam: berdasarkan pendekatan penelitian dan proses pengumpulan data. Adapun jenis penelitian berdasarkan pendekatan adalah kualitatif. Dalam hal ini peneliti mengidentifikasi karakteristik mempertahankan kerukunan umat beragama untuk dieksplorasi kepada makna sosial dan kultural.

\section{Teknik Pengumpulan Data}

Adapun teknik pengumpulan data melalui observasi, wawancara mendalam dan forum group diskusi. Pengumpulan data primer melalui wawancara mendalam kepada pemuka agama, tokoh masyarakat, pemerintah, masyarakat, pedagang, pengunjung wisata rohani Graha Maria Annai Velangkanni Medan Sumatera Utara. Pengumpulan data sekunder dengan melakukan studi pustaka. Dalam melakukan studi kepustakaan ini, dikumpulkan literatur-literatur yang dapat mendukung dalam proses penulisan hasil penelitian. Kemudian data yang telah dikumpulkan, baik data primer maupun sekunder diolah sebagai bahan untuk dieksplorasi atau diungkapkan dalam bentuk tulisan.

\section{Pengujian Keabsahan Data}

Untuk menjamin keabsahan data dalam penelitian ini dilakukan perpanjangan keikutsertaan, ketekunan pengamatan, dan triangulasi 19

1. Perpanjangan keikutsertaan

Perpanjangan keikutsertaan sangat menentukan dalam pengumpulan data. Keikutsertaan tersebut tidak hanya dilakukan dalam waktu singkat, tetapi memerlukan perpanjangan keikutsertaan peneliti. Perpanjangan keikutsertaan penelitian akan memungkinkan peningkatan derajat kepercayaan data yang dikumpulkan.

2. Ketekunan pengamatan

Ketekunan pengamatan bermaksud menemukan ciri-ciri dan unsur-unsur dalam situasi yang sangat relevan dengan persoalan atau isu yang sedang dicari dan kemudian

${ }^{19}$ Muhammad Yunus, "Prosiding Seminar Nasional Pengelolaan Daerah Aliran Sungai (DAS) Secara Terpadu 2017 - Pslh" (Riau: Lembaga Penelitian dan Pengabdian kepada Masyarakat (LPPM) Universitas Riau, Prosiding Seminar Nasional Pengelolaan Daerah Aliran Sungai secara Terpadu: I, 2017). 
memusatkan diri pada hal-hal tersebut secara terperinci. Dengan kata lain, jika perpanjangan keikutsertaan menyediakan lingkup maka ketekunan pengamatan menyediakan kedalaman.

3. Triangulasi

Triangulasi yaitu teknik pemeriksaan keabsahan data yang memanfaatkan sesuatu yang lain diluar data itu untuk keperluan pengecekan atau sebagai perbandingan terhadap data itu. Hal itu dapat dicapai dengan jalan membandingkan data hasil pengamatan dengan data hasil wawancara.

Adapun analisis yang peneliti lakukan dalam menjamin keabsahan data penelitian ini adalah ketekunan pengamatan bermaksud menemukan unsur-unsur dalam situasi yang relevan dengan persoalan atau isi yang sedang dicari dan kemudian memutuskan hal-hal tersebut secara rinci.

\section{HASIL PENELITIAN}

\section{TEMUAN UMUM}

Beragamnya suku agama ras antara golongan yang mengunjungi Graha Maria Annai Velangkanni tentu banyak aspek yang hendak dikaji. Aspek tentang harmonisasi serta kerukunan sebagai wujud nilai pendidikan agama Islam dari kajian pendidikan bertoleransi. Pendidikan bertoleransi masyarakat di sekitar Graha Maria Annai Velangkanni saling menghargai. Aspek pembauran budaya, aspek westernisasi yang semakin meluas. Perilaku, sikap strategi muslim di sekitar Graha Maria Annai Velangkanni mampu mempertahankan kerukunan beragama tanpa lekang oleh era disrupsi. Di mana era yang semakin membuat manusia menghandalkan dunia maya tanpa ada realitas.

Dari segi lokasi penelitian ditemukan bahwa di sekitar Graha Maria Annai Velangkanni yaitu masyarakat muslim di komplek perumahan Sakura Indah Tanjung Selamat Medan Tuntungan. Masyarakat muslim inilah yang berbaur langsung dengan pengunjung Graha Maria Annai Velangkanni. Masyarakat yang beragama dari latar belakang pendidikan, suku, agama, ras dan golongan.

\section{TEMUAN KHUSUS}




\subsection{Strategi muslim mempertahankan kerukunan beragama sebagai wujud nilai pendidikan bertoleransi di sekitar Graha Maria Annai Velangkanni Sumatera Utara Medan.}

Untuk menggali nilai pendiidkan bertoleransi yang dilaksanakan masyarakat di sekitar Graha Maria Annai Velangkanni, peneliti melakukan wawancara dengan masyarakat muslim, pemuka agama, tokoh masyarakat, pengunjung graha, pengurus graha, pemerintah setempat, pengurus organisasi keagamaan, pengurus organisasi kemasyarakatan, tentang strategi muslim mempertahanakan kerukunan umat beragama. Bahwa strategi yang dilakukan adalah, sebagaimana penuturan pengurus Graha Velangkani bahwa:

"masing-masing penganut agama menjalankan ajaran agama. Agama Hindu mengamalkan ajaran agamnya untuk saling menghargai. Agama Budha berupaya saling kerja sama dan bebuat baik, Agama Protestan menjalin cinta kasih dan saling menyayangi. Agama Islam selalu bersilaturahmi dan bertoleransi. ${ }^{20}$

Strategi yang dilakukan adanya saling berupaya melakukan yang terbaik. Di mana strategi yang dilakukan didorong oleh niat dan prinsif ajaran agama masing-masing. Adanya niat dan prinsif yang baik menjadikan setiap masyarakat yang di sekitar Graha Velangkani baik pengunjung ataupun masyarakat yang berdomisili di daerah tersebut berupaya membangun komunikasi dengan sesama masyarakat di sekitar graha. Bukti komunikasi yang bagus di mana pemerintah memberikan perhatian penuh juga kepada pengurus Graha Velangkani, kepada masyarakat muslim dengan mengadakan berbagai kegiatan, antara lain:

Mengadakan dialog dan pertemuan antar beberapa pemuka agama yang beda agama, melakukan persamaan persepsi dan visi masing-masing. ${ }^{21}$

Dilakukannya pertemuan untuk membicarakan segala hal yang berkenaan dengan penuh kedamaian dan toleransi. Pertemuan diusahakan tidak ada saling menyinggung perasaan antar agama. Masing-masing saling berusaha agar tujuan tercapai. Strategi muslim dalam rangka menciptakan kerukunan umat sebagai wujud dari pendidikan bertoleransi.

Masyarakat muslim juga melakukan strategi kerukunan umat beragama dengan jalan membangun muamalah antara umat beda agama. Di mana masing-masing utusan,

\footnotetext{
${ }^{20}$ Pengurus Gaha Velangkani (Wawancara: 2 Januari 2020)

${ }^{21}$ Kepala Lingkungan Sakura Indah ( Wawancara: 3 Januari 2020)
} 
masyarakat yang mempunyai misi tertentu dapat dicapai dengan cara mematuhi nilai-nilai luhur bangsa Indonesia. ${ }^{22}$

Pelaksanaan strategi muslim dalam kerukunan umat beragama sebagai wujud nilai pendidikan bertoleransi sangat membangun kemashlahatan umat. Masing-masing masyarakat muslim membangun harmonisasi beragama dengan dibentengi oleh niat dan kesadaran sesama manusia. Masyaraakat muslim di sekitar Graha Velangkani membangun budaya-budaya sosial dalam satu lingkaran geografis menjadikan ada kerja sama. Startegi masyarakat muslim berusaha untuk mewujudkan terbangunnya pendekatan sosial dan kekeluargaan demi terciptanya pemahaman nilai-nilai luhur, nilai-nilai budaya. ${ }^{23}$

Muslim yang senantiasa berperan serta dalam masyarakat dengan asas saling mempunyai tanggung jawab terhadap masing-masing agama yang dianut berupaya untuk membangun komunikasi yang satu penafsiran agar umat saling memahami dan saling memaknai. Masyarakat telah terbangun satu kesatuan jiwa dalam urusan bersosial dan bermasyaraka. Masyarakat lebih membutuhka kedamaian dan kebahagiaan.

\subsection{Faktor pendorong masyarakat muslim mempertahankan kerukunan beragama sebagai wujud nilai pendidikan bertoleransi di sekitar Graha Maria Annai Velangkanni Sumatera Utara Medan.}

Nilai pendidikan bertoleransi dapat terwujud jikalau strategi yang dilakukan saling ditanggungjawabi setiap masyarakat. Masyarakat yang saling menghargai, menghormati dan saling berupaya mewujudkan komunikasi yang tidak beda persepsi maka dapat terwujud nilai pendidikan yang bertoleransi. Adapun faktor yang mendorong masyarakat mempertahankan kerukunan beragama sebagai wujud nilai pendidikan bertoleransi di sekitar Graha Velangkani sebagai berikut:

a. Faktor dari masyarakat sekitar Graha Velangkani, masyarakat Velangkani yang terdiri dari masyarakat heterongen senantisa saling berupaya mewujudkan nilai pendidikan bertoleransi. Masyarakat yang beragama Islam berupaya menjalin silaturrahmi dengan sesame penganut agama lainnya. Adanya faktor kesadaran dan saling membesarkan

${ }^{22}$ Mutiara, Masyarakat Muslim di Perumahan Sakura Indah di sekitar Graha Velangkani (Wawancara: 4 Januari 2020)

${ }^{23}$ Silaban, pengurus pemerintah di sekitar Gaha Velangkani daerah Perumahan Sakura Indah Medan Tuntungan (Wawancara:5 Januari 2020). 
sesama makhluk ciptaan Tuhan menjadikan suasana yang damai serta teratur di sekitar Graha Velangkani dalam rangka mewujudkan nilai pendidikan toleransi.

b. Faktor dari pengunjung Graha Velangkani, Berkunjung ke Graha adalah bukti adanya niat untuk mempelajari bidaya dan adat agama yang berbeda. Masyarakat muslim yang berkunjung ke Graha Velangkani adalah berupaya untuk mempelajari nilai-nilai peradaban pendidikan. Di Graha Velangkani diperoleh pendidikan multicultural. Pendidikan yang saling bermakna dalam keberagaman.

c. Faktor dari Pemerinah setempat. Pemerintah merupakan pemimpin pengelola masyarakat. Pemerintah menunjukkan sikap kepemimpinannya dalam menjalin keutuhan dan kerukunan. Pemerintah memberikan kebebasan bekerja sama, bergaul dengan tidak merusak aqidah agama masing-masing. Faktor keterbukaan dari pemerintah menjadikan masyarakat muslim semakin semangat untuk menjalin kerja sama dan persaudaraan dengan sesama masyarakat lainnya sebagai wujud nilai pendiidkan bertoleransi.

\section{E. PENUTUP}

Penelitian ini mendapatkan data tentang variasi tingkat kerukunan umat beragama di masyarakat muslim sekitar Graha Maria Annai Velangkanni yang multi etnis. Strategi masyarakat muslim mempertahankan kerukunan beragama di sekitar Graha Maria Annai Velangkanni Sumatera Utara Medan sebagai bukti ejawantah Q.S Almaidah ayat 48. Faktor pendorong masyarakat muslim mempertahankan kerukunan beragama di sekitar Graha Maria Annai Velangkanni Sumatera Utara Medan di era disrupsi antara lain sebagai bukti bahwa ada niat dalam menjalankan nilai ajaran pendidikan agama Islam dari nilai pendidikan bertoleransi.

\section{DAFTAR PUSTAKA}

Ahmad, Haidlor Ali. Survey Kerukunan Umat Beragama Di Indonesia. Jakarta: Puslitbang Kehidupan Keagamaan Badan Litbang dan Diklat Kementerian Agama RI, 2013.

Anggito, Albi \& Setiawan, Johan. "Metodologi Penelitian Kualitatif." Sukabumi: Jejak, 2018. https://books.google.co.id/books?id=59V8DwAAQBAJ\&printsec=frontcover\&dq=metode+ penelitian+sugiyono\&hl=id\&sa=X\&ved=0ahUKEwio3KSekfzgAhXGXCsKHSmxAdgQ6 AEINTAD\# $\mathrm{v}=$ onepage $\& \mathrm{q}=$ metode penelitian sugiyono $\& \mathrm{f}=$ false .

Arifinsyah, Saidurrahman \&. Nalar Kerukunan_Merawat Keragaman Bangsa Mengawal NKRI. Jakarta: Kencana, 2018. 
Aris Ridiana, Reza Bakhtiar Ramadhan. "Dakwah Virtual Sebagai Banalitas Keberagaman Di Era Disrupsi.” Jurnal Ilmu Aqidah Dan Studi Keagamaan 7, no. 1 (2019)

Asfi Manzilati. "Metodologi Penelitian Kualitatif: Paradigma, Metode, Dan Aplikasi." Malang: Universitas Brawijaya $\quad$ Press, 2017. https://books.google.co.id/books?hl=en\&lr=\&id=7FlVDwAAQBAJ\&oi=fnd\&pg=PR5\&dq =subyek+dan+obyek+penelitian\&ots=Y57y9h_rf_\&sig=DIZKusqDHiczY9UXiM2idssh6nI \&redir_esc=y\#v=onepage \&q=subyek dan obyek penelitian\&f=false.

Asfiati. Pendekatan Humanis Dalam Pengembangan Kurikulum. Bandung: Perdana Publishing, 2016.

Bharatputra, James. "Mengenai Graha Maria Annai Velangkanni,” 2019.

Hadi, Rahmini. "Pola Kerukunan Umat Beragama Di Banyumas." Ibda Jurnal Kebudayaaan Islam IV, no. 1 (2016)

Hakis. "Komunikasi Antar Umat Beragama Di Kota Ambon.” Jurnal Komunikasi Islam 05, no. 1 (2015)

Herwina, Iswan dan. "Penguatan Pendidikan Karakter Persfektif Islam Dalam Era Millenial IR $\begin{array}{llllll}\text { 4.0." } U m j & 1, & \text { no. } & 1 & \text { (2018): } & \text { 21-42. }\end{array}$ https://jurnal.umj.ac.id/index.php/SNP/article/view/2756/2261.

Kusumastuti, Erwin. "Strategi Dan Praktek Kerukunan Beragama Dalam Persfektif Pendidikan Multikultural: Studi Di Desa Ponggok, Polanharjo , Klaten,” 2016.

Luthfiyah, Muh. Fitrah \&. "Metodologi Penelitian: Penelitian Kualitatif, Tindakan Kelas \& Studi Kasus.” Sukabumi: Jejak, 2018.

Mawardi. "Reaktualisasi Kerukunan Antar Umat Beragama Dalam Kemajemukan Sosial." Substantia 17, no. April (2015)

Murni, Dewi. “Toleransi Dan Kebebasan Beragama Dalam Persfektif Al-Quran.” Jurnal Syahadah VI, no. 2 (2018)

Nazmudin, Nazmudin. "Kerukunan Dan Toleransi Antar Umat Beragama Dalam Membangun Keutuhan Negara Kesatuan Republik Indonesia (NKRI)." Journal of Government and Civil Society 1, no. 1 (2018): 23. https://doi.org/10.31000/jgcs.v1i1.268.

Nursyaidah. "Metodologi Penelitian Disertai Dengan Contoh Penerapannya Dalam Penelitian," 2018.

Roikan, S.Aminah \&. "Pengantar Metode Penelitian Kualitatif." Jakarta: Prenameda Group, 2019. 
Rusydi, Ibnu, and Siti Zolehah. "Makna Kerukunan Umat Beragama Dalam Konteks Keislaman Dan Keindonesian." Journal for Islamic Studies 1, no. 1 (2018): 170-81. https://doi.org/10.5281/zenodo.1161580.

Salim, Muhammad. "Implementasi Pendekatan Saintifik Dalam Pembelajaran Pendidikan Agama Islam Dan Budi Pekerti Di Sd Negeri Baran, Patuk, Gunungkidul." UIN Sunan Kalijaga, 2017.

Utami, Kartika Nur. "Kebebasan Beragama Dalam Perspektif Al-Qur'an." Kalimah. Jakarta: Infas, 2018. https://doi.org/10.21111/klm.v16i1.2511.

Wikipedia. "Wikipedia Bahasa Indonesia, Ensiklopedia Bebas," 2018. https://id.wikipedia.org/wiki/Fotosintesis.

Wikipedia bahasa Indonesia, ensiklopedia bebas. "Tanjung Selamat, Medan Tuntungan, Medan,” 2019.

Yunus, Muhammad. "Prosiding Seminar Nasional Pengelolaan Daerah Aliran Sungai (DAS) Secara Terpadu 2017 - Pslh." Riau: Lembaga Penelitian dan Pengabdian kepada Masyarakat (LPPM) Universitas Riau, Prosiding Seminar Nasional Pengelolaan Daerah Aliran Sungai secara Terpadu: I, 2017. 